\title{
Porphyria cutanea tarda and haemochromatosis: a family study
}

\author{
D G Seymour, G H Elder, A Fryer, A Jacobs, G T Williams
}

\begin{abstract}
A female patient aged 73 presented with a history of general malaise and hyperpigmentation. Iron studies in the patient and immediate family members indicated that the proband was homozygous for haemochromatosis, but subsequent investigations revealed that porphyria cutanea tarda was responsible for her signs and symptoms. Venesection of four units of blood brought her symptoms under control. The interplay between porphyria cutanea tarda and excess iron deposition is discussed as is the role of extending investigations to first and second degree relatives when either haemochromatosis or porphyria cutanea tarda is suspected.
\end{abstract}

Hyperpigmentation and a high transferrin saturation may be encountered in both haemochromatosis and porphyria cutanea tarda, and diagnostic difficulties may arise. Studies of other family members may be informative as the following report indicates. We also discuss the general relationship between sporadic porphyria cutanea tarda, abnormal iron status, and the possession of one or more alleles for haemochromatosis.

\section{Case report and family study}

\section{CLINICAL FEATURES OF PROBAND}

A woman aged 73 years was admitted to hospital in June 1987 complaining of anorexia and general malaise for three months. She had always had a 'dark complexion', but in the last three months the pigmentation had become more pronounced over the light exposed areas of her face and arms, despite minimal sun exposure. She also commented on an increase in hair on the upper lip and over the temples.

A working diagnosis of haemochromatosis was arrived at on the following evidence: serum ferritin $636 \mu \mathrm{g} / \mathrm{l}$ (normal range 20-300 $\mu \mathrm{g} / \mathrm{l}$ ); serum iron $63 \mu \mathrm{mol} / 1$ (normal range $11-30$ $\mu \mathrm{mol} / \mathrm{l}$ ); transferrin saturation $94 \%$ (normal range $20-50 \%$ ); and a history of adult onset diabetes mellitus. This diagnosis seemed to be supported by a liver biopsy specimen which showed moderate fatty change with excessive deposition of coarse iron granules in hepatocytes and Kupffer cells throughout most of the hepatic lobule (grade 3-4). There was no evidence of cirrhosis, liver cell necrosis, or inflammation. Clinically, the liver was palpable $2 \mathrm{~cm}$ below the costal margin but was of normal consistency. While the serum $\gamma$ glutamyltransferase was raised at $84 \mathrm{IU} / 1$ (normal range $<40 \mathrm{IU} / \mathrm{l}$ ), the serum albumin, bilirubin, alkaline phosphatase, and alanine transaminase were all in the normal range. A screening test for urinary porphyrins was normal, as was a short synacthen test.

Four years earlier investigations in another unit had been undertaken after a complaint of weight loss and general malaise. A liver biopsy specimen at that time had shown fatty change and excess iron deposition, which had been interpreted as consistent with alcohol abuse, although this was strongly denied by the patient and her family. At that time serum ferritin was $970 \mu \mathrm{g} / \mathrm{l}$, serum iron $37 \mu \mathrm{mol} / \mathrm{l}$, and transferrin saturation $74 \%$, but the patient defaulted from follow up before further investigations could be performed. Serum analysis had also identified an IgG kappa paraprotein band.

In view of the diagnosis of haemochromatosis a series of venesections was planned and the Institute of Medical Genetics undertook to screen immediate family members for signs of abnormal iron state, as haemochromatosis is an autosomal recessive disorder.

\section{FINDINGS OF FAMILY STUDY}

As the Figure shows the proband (II-3) had a brother (II-4) aged 68 whose transferrin saturation was $55 \%$, suggesting heterozygosity for the haemochromatosis gene.' The proband's sister (II-1) was aged 65 and had a transferrin saturation of $32 \%$, which although in the normal range is also compatible with heterozygosity. It is customary to screen siblings of patients with haemochromatosis as they are at a $25 \%$ risk of being homozygotes. The haemochromatosis gene is common in the general population, approximately $10 \%$ of whites being carriers, ${ }^{2-4}$ and so wider screening of second degree relatives is also logical. ${ }^{5}$ The proband's only son declined to be tested and is therefore not shown in the figure, but the proband's niece (III-1) had a transferrin saturation of $98 \%$ with a serum ferritin concentration of $484 \mu \mathrm{g} / \mathrm{l}$. It is therefore highly likely that she is homozygous for the haemochromatosis gene.' She was not pigmented, but had developed a non-erosive seronegative arthropathy in November 1987 which may have been due to iron deposition. She had a history of menorrhagia which may have protected her from the more serious effects of iron overload. She also had congenital absence of a breast, but this is usually a sporadic event and was not thought to be related to her haemochromatosis. We concluded that the niece (III-1) had inherited one haemochromatosis gene from her mother (II-1) and one from her late father (II-2). HLA typing of the family indicated that her father must have had the haplotype A3, B7, which is commonly associated with haemochromatosis. ${ }^{56}$ 


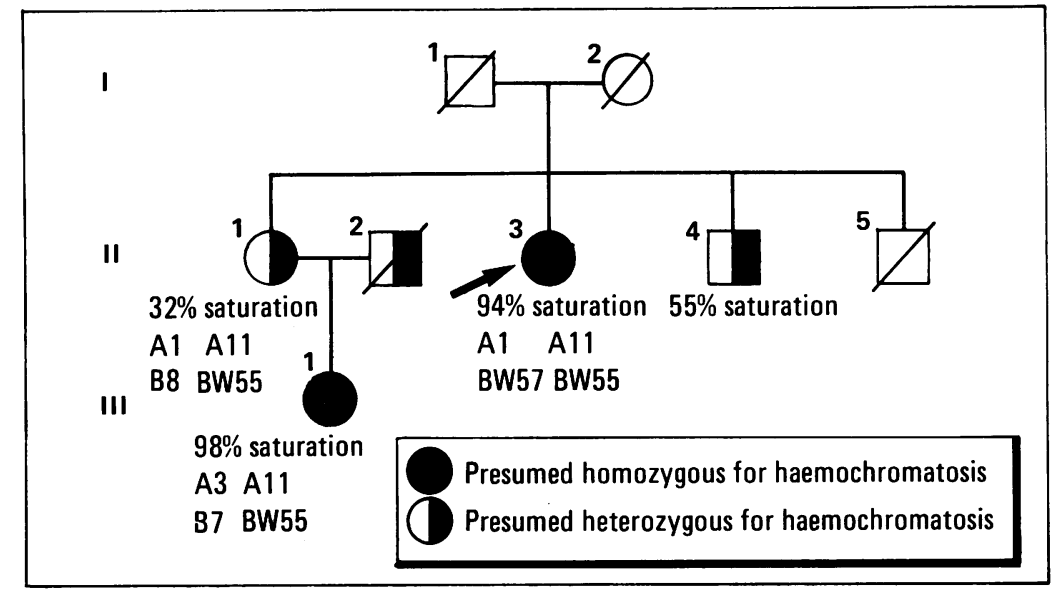

Transferrin saturations and HLA typing of siblings and niece of proband.

REASSESSMENT OF THE DIAGNOSIS OF HAEMOCHROMATOSIS IN THE PROBAND The proband was treated by venesection, which led to a re-evaluation of the diagnosis of haemochromatosis because by removing only two units of blood the transferrin saturation was reduced from $94 \%$ to $44 \%$, while the serum ferritin concentration fell from $636 \mu \mathrm{g} / \mathrm{l}$ to $313 \mu \mathrm{g} / \mathrm{l}$. The extent of this response is much greater than would be expected in haemochromatosis where 20 to 30 venesections are usually required before the iron state becomes normal. ${ }^{7}$ The response to venesection is much more in keeping with the modest degree of iron overload found in porphyria cutanea tarda, where an average of five venesections is usually sufficient to return the iron state to normal and to induce a remission in the porphyria cutanea tarda. ${ }^{8-10} \mathrm{~A}$ diagnosis of porphyria cutanea tarda would also explain the proband's facial hirsutism. Although urine porphyrin screening had been normal on initial assessment, a repeat investigation showed a pattern of increased porphyrin excretion that was diagnostic: total urinary porphyrin 1560 $\mathrm{nmol} / \mathrm{l}$ (mainly uroporphyrin and heptacarboxylic porphyrin; normal range $20-320 \mathrm{nmol} / \mathrm{l}$ ) with an increased concentration of isocoproporphyrin in the faeces.

To add further support to the diagnosis of porphyria cutanea tarda in the proband, unstained formalin fixed paraffin sections of the liver biopsy specimens from 1983 and 1987 were examined under polarised light for porphyrin crystals. None were found in the first biopsy specimen, but several small, needle shaped crystals typical of porphyria cutanea tarda were present in the hepatocytes in the second specimen. These crystals are water soluble and are easily dissolved out of the tissues during routine fixation, which may explain the failure to find them in the earlier biopsy specimen. The diagnosis of porphyria cutanea tarda in the proband was therefore established on biochemical and histological grounds. In the 12 months after the diagnosis was established four venesections of $500 \mathrm{ml}$ each achieved clinical remission of the porphyria cutanea tarda and returned the ferritin level to normal.

Porphyrin studies in the proband's sister (II-1) and niece (III-1) were normal (total urinary porphyrin concentration $<65 \mathrm{nmol} / 1$; faecal por- phyrin concentration $<95 \mathrm{nmol} / \mathrm{g}$ dry weight with no detectable isocoproporphyrin). Uroporphyrinogen decarboxylase concentrations in erythrocytes from the proband, her sister, and her niece ranged from $71-108 \%$ of the mean concentration in control subjects. The porphyrin studies suggest that the proband had sporadic (type I) porphyria cutanea tarda," while the earlier iron studies indicated the presence of at least one (and probably two) genes for haemochromatosis.

\section{Discussion}

Patients with sporadic (type I) porphyria cutanea tarda are thought to have an underlying susceptibility to the disease (which may be inherited), but in addition they usually have other precipitating factors. The commonest is alcohol, but oral oestrogens and excessive oral iron intake may also lead to clinical manifestations in susceptible individuals. ${ }^{12}$ Alcohol, oestrogens, and excessive iron intake, however, were not features in our proband.

An abnormal iron state is a well recognised feature of porphyria cutanea tarda, even when excess iron does not appear to be the precipitating factor. Thus total body iron stores are often modestly increased, and moderate iron deposition in the liver is common. ${ }^{12}$ The transferrin saturation is also above the normal range in many cases of porphyria cutanea tarda. Thus in a series of 30 patients (at least 25 of whom appeared to have the sporadic rather than the dominantly inherited type), Lundvall $e t a l^{8}$ found a mean transferrin saturation of $60 \%$ with a range of 36 $91 \%$. Similarly, in 20 patients with no family history of disease, Turnbull $e t a l^{13}$ found a mean transferrin saturation of $68 \%$ with a range of 35 $94 \%$. It should be noted, however, that none of the 30 patients of Lundvall et $a l^{8}$ and only two of the 20 patients of Turnbull et $a l^{13}$ had a transferrin level as high as that found in our proband (94\%). The cause of the hepatic siderosis and iron overload in porphyria cutanea tarda is uncertain..$^{14}$ Kushner et $a l^{16}$ proposed that inheritance of at least one allele for HLA linked haemochromatosis is responsible for hepatic siderosis in sporadic porphyria cutanea tarda. Some studies have shown an association between the HLA A3 antigen and porphyria cutanea tarda, whereas others have not. ${ }^{14-17} \mathrm{We}$ postulate that in our proband (II-3) excessive iron absorption due to the presence of one or more alleles for haemochromatosis was the precipitating factor for porphyria cutanea tarda.

As discussed above, transferrin saturations of $60 \%$ are common in porphyria cutanea tarda, but levels over $90 \%$ are rarely encountered. Our findings raise the possibility that a very high transferrin saturation level in a patient with porphyria cutanea tarda implies homozygosity for the haemochromatosis gene, but further clinical observations in similar cases are required.

Our final diagnostic conclusions are as follows. The recent pigmentation of the proband was probably due to porphyria cutanea tarda rather than haemochromatosis, as her response to venesection was more in keeping with the minor degree of iron overload associated with 
porphyria cutanea tarda than with the major iron overload encountered when haemochromatosis is advanced enough to produce clinical signs. The proband's brother is heterozygous for haemochromatosis, shown by his $55 \%$ transferrin saturation. ${ }^{1}$ The proband's niece does not have porphyria cutanea tarda, but her $98 \%$ transferrin saturation strongly suggests that she is homozygous for haemochromatosis. The niece will require occasional venesection, which should prevent haemochromatosis developing. The IgG kappa paraprotein found in the proband is probably coincidental, although there is one case report linking porphyria cutanea tarda and myltiple myeloma. ${ }^{18}$ The question of whether a haemochromatosis gene is present in all cases of porphyria cutanea tarda cannot be answered by a single family study, but our report further highlights the need for systematic research in this area. ${ }^{15}$

Several points for general clinical practice also emerge from this report. Porphyria cutanea tarda can present in old age. While mechanical fragility, blistering, and scarring of the skin are the most common findings, increased pigmentation over areas exposed to the sun may be the only skin findings, as in the present case. As this report also shows, porphyria cutanea tarda is not always detected by urine screening tests. ${ }^{19}$ If clinical suspicion is high the diagnosis should not be rejected unless urinary uroporphyrin and faecal isocoproporphyrin concentrations are normal. In view of the frequent association of porphyria cutanea tarda with hepatic iron overload, and because porphyrin crystals may be seen easily in unstained liver biopsy specimens, we suggest that these crystals should be searched for routinely in all liver biopsy specimens showing excessive iron deposition.
1 Dadone MM, Kushner JP, Edwards CQ, Bishop DT, Skolnick MH. Hereditary hemochromatosis. Analysis of laboratory expression of the disease by genotype in 18 pedigrees. Am F Clin Pathol 1982; 78: 196-207.

2 Beaumont C, Simon M, Fauchet R, et al. Serum ferritin as possible marker of the hemochromatosis allele. New Engl $\mathcal{F}$ possible marker of the hen
Med 1979; 301: 169-74.

3 Tanner AR, Desai S, Lu W, Wright R. Screening for haemochromatosis in the UK; preliminary results [Abstract]. Gut 1985; 26: Al139.

4 Edwards CQ, Griffen LM, Goldgar D, et al. Prevalence of hemochromatosis among 11065 presumably healthy blood donors. New Engl f Med 1988; 318: 1355-62.

5 Edwards CQ, Dadone MM, Skolnick MH, Kushner JP. Hereditary haemochromatosis. Clin Haematol 1982; 11 411-35.

6 Simon M, Fauchet R, Hespel J-P, Brissot P, Genetet B, Bourel $M$. Idiopathic hemochromatosis and HLA. In: Farid NA, ed. HLA in endocrine and metabolic disorders. New York: Academic Press, 1981: 291-323.

7 Sherlock S. Diseases of the liver and biliary system. 7th edition. Oxford: Blackwell Scientific, 1985: 368.

8 Lundvall $\mathrm{O}$, Weinfeld $\mathrm{A}$, Lundin $\mathrm{P}$. Iron storage in porphyria cutanea tarda. Acta Med Scand 1970; 188: 37-53.

9 Lundvall $O$. Phlebotomy treatment of porphyria cutanea tarda. Acta Derm Venerol 1982; Suppl 100: 107-18

10 Grossman ME, Bickers DR, Poh-fitzpatrick MB, Deleo VA Harber LC. Porphyria cutanea tarda. Clinical features and laboratory findings in 40 patients. Am $\mathcal{F}$ Med 1979; 67: 277 86.

11 De Verneuil H, Aitken G, Nordmann Y. Familial and sporadic porphyria cutanea tarda: two different diseases. Hum Genet 1978; 44: 145-51.

12 Kappas A, Sassa S, Anderson KE. The porphyrias. In: Standbury DB, Wyngaarden JB, Fredrickson DS, Goldstein JL, Brown MS, eds. The metabolic basis of inherited disease. 5th edition. New York: McGraw-Hill, 1985

13 Turnbull A, Baker H, Vernon-Roberts B, Magnus IA. Iron metabolism in porphyria cutanea tarda and in erythropoietic metabolism in porphyria cutanea tarda and

protoporphyria. $Q \mathcal{F}$ Med $1973 ; 42: 341-55$.
14 Elder GH. Porphyria cutanea tarda and HLA-linked haemochromatosis. Gastroenterology 1985; 88: 1276-9.
cher

15 Adams PC, Powell LW. Porphyria cutanea tarda and HLAlinked hemochromatosis - all in the family? Gastroenterology 1987; 92: 2033-5.

16 Kushner JP, Edwards CQ, Dadone MM, Skolnick MH Heterozygosity for HLA-linked hemochromatosis as a likely cause of the hepatic siderosis associated with sporadic porphyria cutanea tarda. Gastroenterology $1985 ; 88$ : $1232-8$.

17 por $M$, Nordmann Y Porphyria cutanea haemochromatosis. Gastroenterology 1987; 92: 1833-8.

18 Maier JM, Ungaro PC. Porphyria cutanea tarda in association with multiple myeloma. New Conn Med f 1984; 45: 638-9.

19 Deacon AC. Performance of screening tests for porphyria. Ann Clin Biochem 1988; 25: 392-7. 